\title{
Ontogenesis of testicular function in humans
}

\author{
Virginie Rouiller-Fabre1,2,3, Vincent Muczynski ${ }^{1,2,3}$, Romain Lambrot1,2,3, \\ Charlotte Lécureuil 1,2,3, Hervé Coffigny 1,2,3, Catherine Pairault ${ }^{1,2,3}$, \\ Delphine Moison 1,2,3, Gaëlle Angenard ${ }^{1,2,3}$, Mariana Bakalska ${ }^{4}$, \\ Anne Marie Courtot ${ }^{1,2,3}$, René Frydman ${ }^{5,6}$ and René Habert ${ }^{1,2,3}$
}

\author{
${ }^{1}$ Laboratory of Differentiation and Radiobiology of the Gonads, CEA - DSV / iRCM / SCSR, \\ F-92265 Fontenay aux Roses, France \\ 2Université Paris Diderot-Paris7, F-92265, Fontenay aux Roses, France \\ 3INSERM, Unité 967, F-92265, Fontenay aux Roses, France \\ ${ }^{4}$ Institute of Experimental Morphology and Anthropology, Bulgarian Academy of Sciences, Sofia, Bulgaria \\ ${ }^{5}$ Service de Gynécologie-Obstétrique, Université Paris Sud, UMR 782, Hôpital A. Béclere, \\ F-92141 Clamart, France \\ ${ }^{6}$ INSERM, Unité 782, F-92141 Clamart, France.
}

\begin{abstract}
The two major functions of the testis, steroidogenesis and gametogenesis, take place during fetal life. These two functions have been extensively studied in rodents and adult humans. However, their onset during fetal life is poorly documented in humans. In the first part of this work we presented both our experimental data and some data of literature concerning the development of the human fetal testis. In the second part of this article, using the organ culture system we previously developed, we have investigated the regulations or perturbations of fetal testis development both in rodent and human models. Our findings provide important insight into the potential role of exposure to environmental pollutants (physical factors, in particular ionizing radiation, cadmium and endocrine disruptors such as phthalates) during fetal testicular development and their potential deleterious effects on male fertility in adulthood. Our results highlight the specificity of the human model compared with rodent models.
\end{abstract}

Key words: human, fetal, testis, development, germ cells, Sertoli cells, Leydig cells.

\section{Introduction}

The two major functions of the testis, steroidogenesis and gametogenesis, take place during fetal life (Fig. 1). This period is critical for the testicular function in the adult. Differentiation and development of the male reproductive tract is critically dependent on normal testicular development. Androgen, INSL3 and antiMullerian hormone, secreted by Leydig cells and Sertoli cells (Fig. 1), ensure masculinization of the internal ducts and normal development of the male phenotype. In the human, testicular differentiation begins at about 6 weeks after conception with the gradual devel-

Correspondence: V. Rouiller-Fabre (Professor), Unit of Gametogenesis and Genotoxicity, LDRG / SCSR / iRCM / DSV, Centre CEA, BP6, F-92265, Fontenay aux Roses, France; e-mail: virginie.rouiller-fabre@cea.fr opment of testicular cords containing Sertoli cells and primordial germ cells (PGCs). The number of germ and Sertoli cells formed during fetal life is essential for adult fertility (Fig. 1).

Our laboratory has for several years focused its research on the ontogenesis of gametogenesis and steroidogenesis. These two functions have been extensively studied in rodents and adult humans. However, their onset during fetal life is poorly documented in humans. Six years ago, we established collaboration with the Department of Obstetrics and Gynecology of R Frydman at the Antoine Béclere Hospital. Testes are obtained after legal abortion during the first trimester of pregnancy, which is a critical period for testis differentiation.

The aim of this article is to present recent data on the development of testicular function in humans and to show how this development can be regulated or disturbed. 


\section{STEROIDOGENESIS}

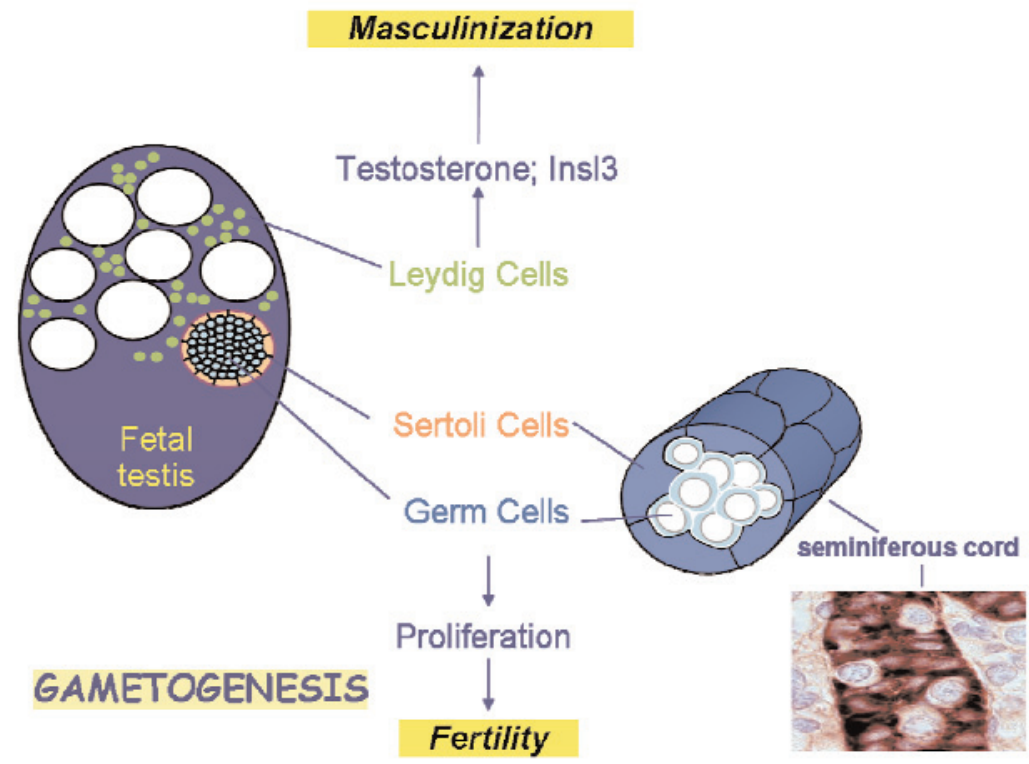

Fig. 1. Development of testicular function during fetal life. Schematic representation of the two major functions, spermatogenesis and steroidogenesis. The micrograph shows immunohistological staining of anti-Mullerian hormone in a human seminiferous cord at 7-8 weeks of gestation.

\section{Chronology of testicular development}
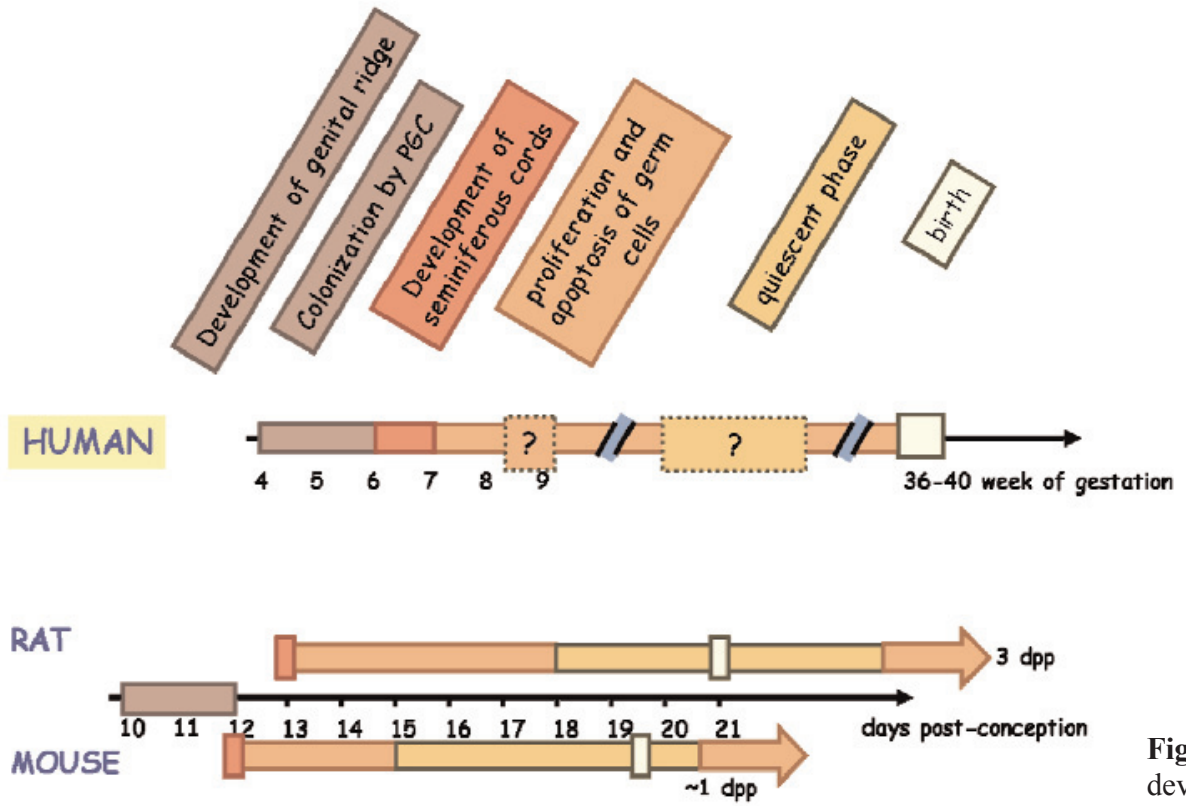

Fig. 2. Comparative chronology of fetal testis development in humans, rats and mice.

During the initial phase of sexual development, the gonads develop in a non-sex-specific manner, being morphologically identical in XX and XY embryos, and are therefore named bipotential gonads. Concerning the chronology of testicular development in humans, PGCs, the founders of the germ line, start migrating from the stalk of allantois at 4 weeks of gestation and enter the bipotential gonad in the fifth week [1] (Fig.
2). In males, the PGCs are then enclosed by the differentiating Sertoli cells. Thus, the first morphological sign of testicular differentiation is the formation of testicular cords, which can be seen between 6 and 7 weeks of gestation (Fig. 2) [1,2]. At this stage and throughout gestation, Sertoli cells start to produce antiMullerian hormone (Fig. 3). Using an organotypic culture system, we have shown that the formation of sem- 
Development of testicular functions in human

Ontogenesis of testicular cells

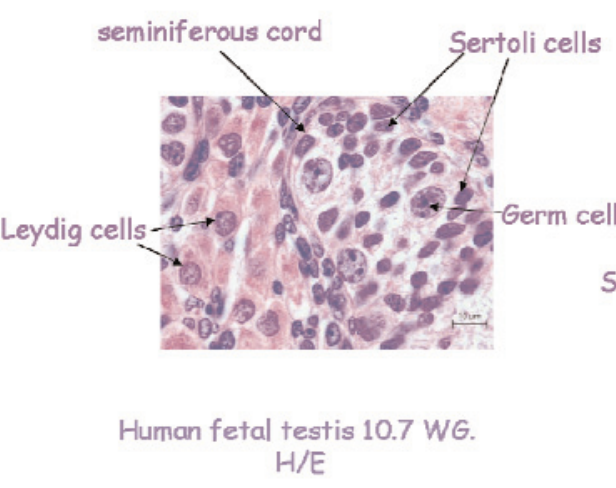

Sertoli cell

$$
H / E
$$

\section{Development of testicular functions in human: Ontogenesis of germ cells}

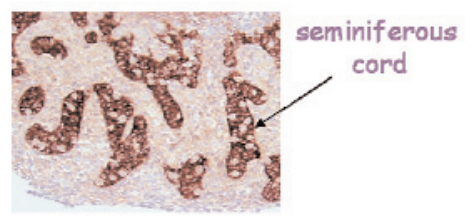

germ cell

Human fetal testis 7-8 WG Immunodetection of AMH
Fig. 3. A: Histological micrograph of human fetal testis (10.7 weeks of gestation) stained by hematoxylin/ eosin, with the different cell types and structures. B: Immunohistological staining of anti-Mullerian hormone showing seminiferous cords in a human fetal testis (7-8 weeks of gestation) and the negatively stained germ cell.
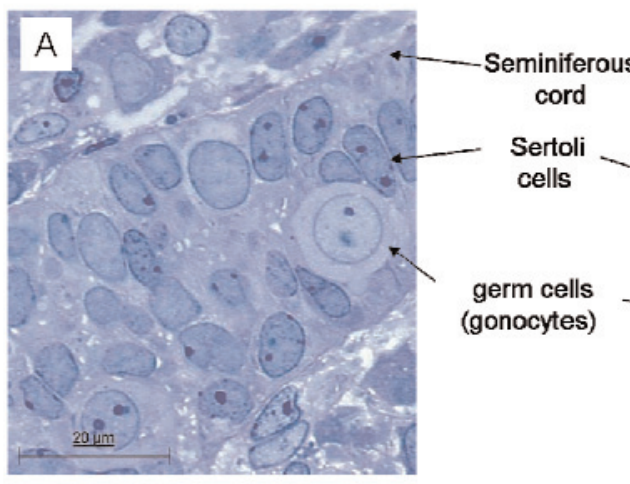

Collaboration with M. BAKALSKA: Institute of experimental morphology and anthropology, Bulgaria
Fig. 4. Semithin section and electron micrograph of a male germ cell inside a seminiferous cord in a human fetal testis. iniferous cords can be obtained in vitro without adding any factors. Sertoli cells proliferate in seminiferous cords, and we have shown in vitro that their rate of proliferation is about $2-3 \%$, and less than $1 \%$ of the cells are apoptotic. These data are in accordance with the studies of Bendsen and O'Shaughnessy indicating that Sertoli cells increase regularly in number during the first and second trimesters of gestation $[3,4]$.

Concerning the ontogenesis of germ cells, these cells appear in semithin sections or under the electron microscope as big cells with a round nucleus and clear cytoplasm (Fig. 4). In rodents, the germ cells are named gonocytes throughout fetal life [5]. In humans, fetal germ cells were first characterized using morphological criteria. Several different types of human testicular germ cells were found and their names vary according to the research teams $[1,6,7]$. Recently, an immunohistochemical study using germ cell markers characterized three different types of human testicular germ cells: gonocytes, intermediate germ cells, and prespermatogonia [6] (Fig. 5). It is important to note that the different types of germ cells are present at the same age, indicating that the population of germ cells is very heterogeneous. Not all the cells of one subpopulation express every marker. For example, only $74 \%$ of gonocytes express Oct 3/4 [8]. Lastly, it is interesting to note that several markers of human fetal germ cells, such as AP2 $\gamma$, 
Development of testicular functions in human: Ontogenesis of germ cells

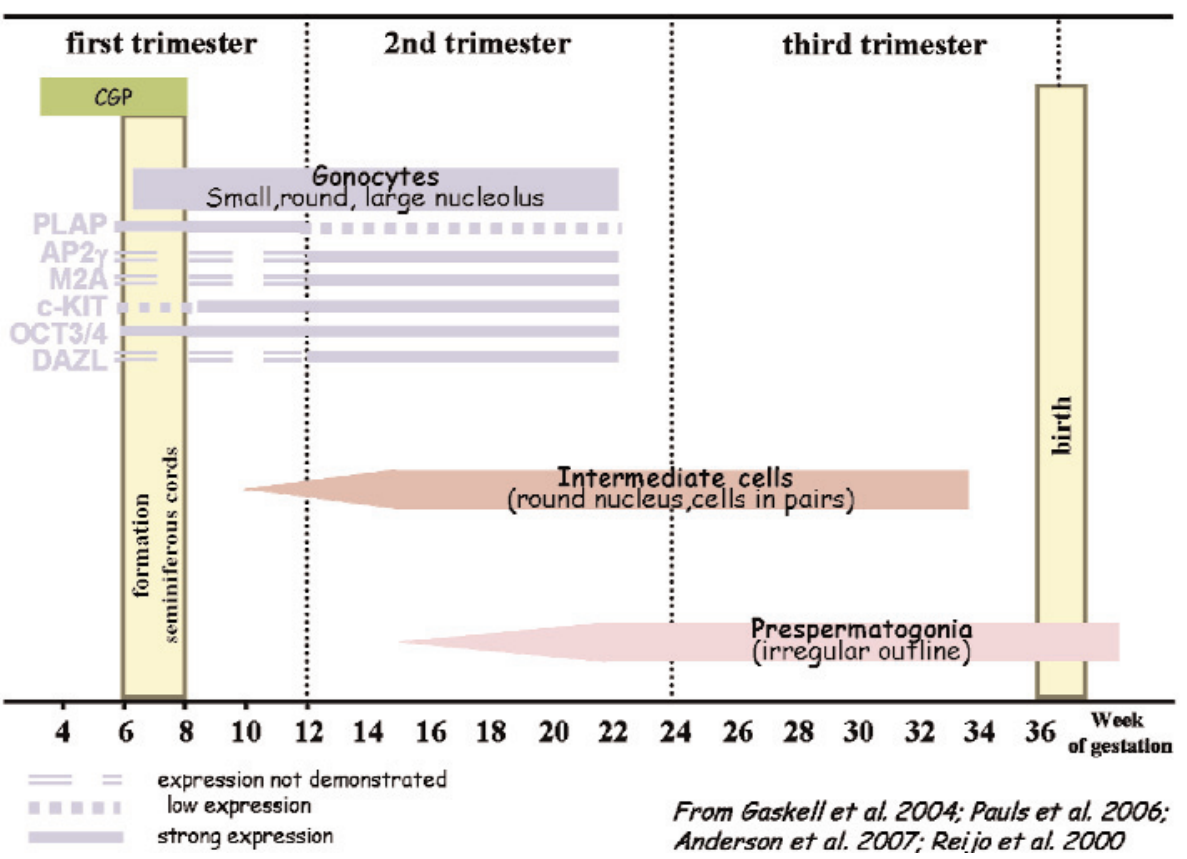

\section{Chronology of testicular development}
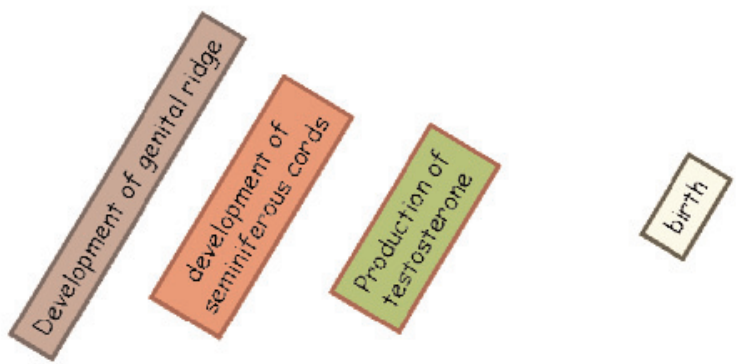

HUMAN

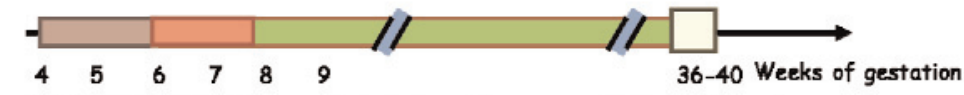

First trimester 2nd trimester

third trimester

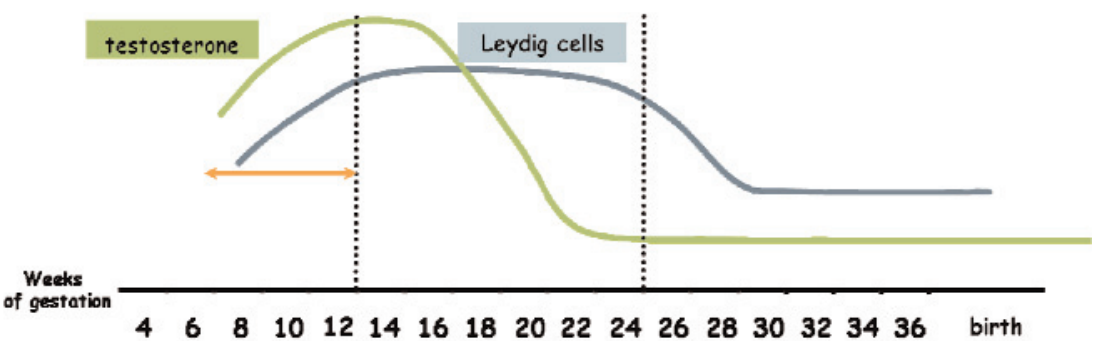

Fig. 5. Chronology of human male fetal germ cell development and expression of different markers in gonocytes.
Fig. 6. Chronology of steroidogenic function in human fetal testis, including testosterone level and Leydig cell number.
M2A and Oct 3/4 (Fig. 5), are found in adult testicular cancer cells [9].

During the first trimester of gestation, we have shown that the rate of proliferation of gonocytes is about $25-30 \%$, and about $2 \%$ of the cells are apoptotic. These data are in accordance with the studies of Bendsen and O'Shaughnessy indicating that germ cells increase regularly in number during the first and second trimesters of gestation $[3,4]$. In rodents, the gonocytes proliferate in the seminiferous cords until fetal day 18.5 (rat) or 15.5 (mouse), after which they become quiescent until postnatal day 2- 
Development and regulations of testicular functions in human

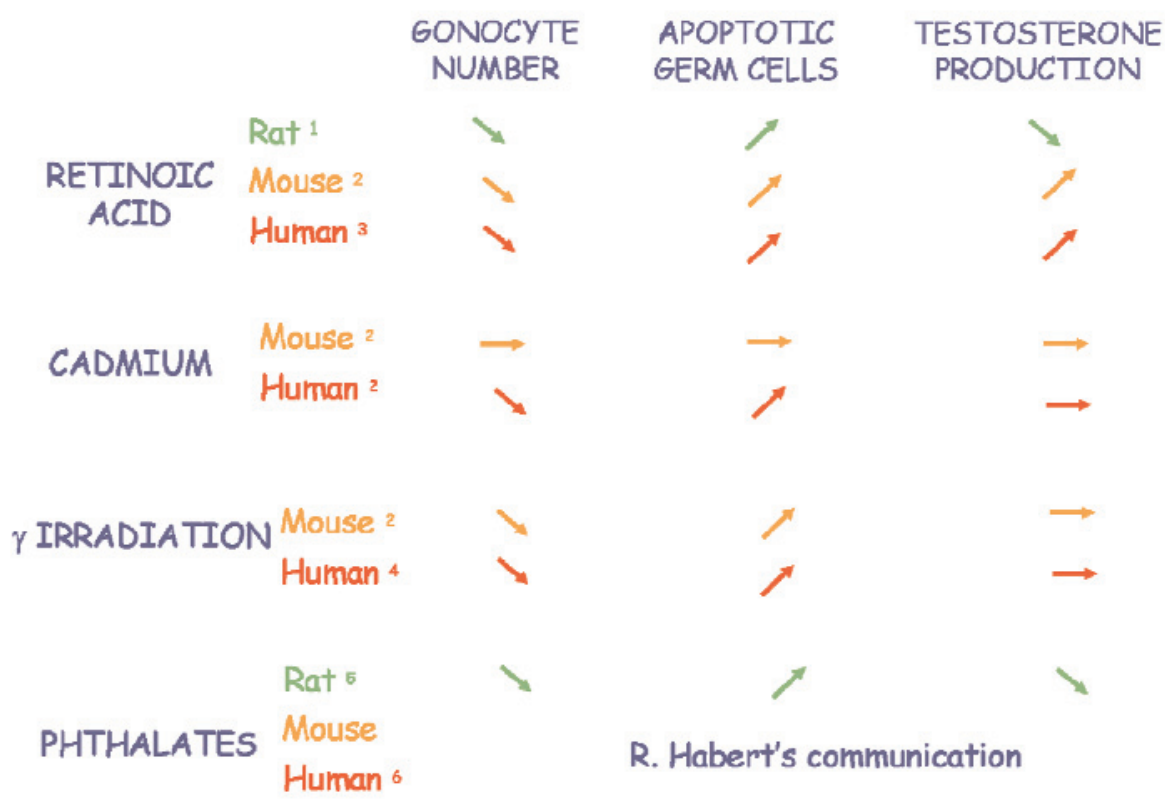

1: Livera et al, Biol Reprod 2000; 2: Personal data; 3: Lambrot et al., JCEM 2006; 4: Lambrot et al., JCEM 2007; 5: Chavvigne et al EHP 2009 ; 6: Lambrot, Muczynski et al, EHP 2009
Fig. 7. Comparative summary of the effects of various factors on testicular function in rat, mouse and human testis, in the organotypic culture system.
3 (rat) or birth (mouse), when they resume mitosis (Fig. 2).

Nevertheless, in humans, such alternate periods of activity (mitosis and apoptosis) and quiescence have never been reported and the rate of proliferation observed in our study suggests that the quiescent phase does not exist during the first trimester.

The steroidogenic function of human fetal testis is better documented. Steroid-secreting Leydig cells can be seen in the testis at 8 weeks of gestation [10]. At this period, the concentration of androgens in the testicular tissue and blood starts to rise, peaking at 14-16 weeks of gestation [11,12] (Fig. 6). This increase comes with an increase in the number of Leydig cells [11]. During the first trimester of gestation we have shown that testosterone secreted in vitro increases strongly since at 7 weeks of gestation testis produced about 10 $\mathrm{pg} /$ testis/hour, whereas at 12 weeks of gestation the production reaches $10000 \mathrm{pg} /$ testis/hour.

In the second part of this article, we investigate the regulations or perturbations of human fetal testis development. We have developed an organ culture system in which the architecture of the testis and intercellular communications are conserved $[13,14]$. This in vitro system allows us to mimic the development of Sertoli cells, gonocytes and Leydig cells observed in vivo, with no need to add serum or other factors. It is, of course, the only approach usable for experimental studies in humans. Using it, we have shown the importance of vitamin A and its biologically active metabo- lite, retinoic acid, during the development of rat [15], mouse (unpublished data) and human testis [16]. We have also used it to study the effects of heavy metals (cadmium and uranium), $\gamma$ irradiation (Lambrot et al. 2007) and endocrine disruptors (such as phthalates) in humans (Lambrot* and Muczynski* et al. 2009). We have shown that in the three species studied, retinoic acid reduces the number of gonocytes by increasing their apoptosis. For steroidogenic function, retinoic acid reduces testosterone production in rats [15], but increases it both in mice (unpublished data) and humans [16] (Fig. 7). Concerning the effect of cadmium, human fetal testis seems particularly sensitive compared with the mouse model. Indeed, a cadmium concentration as low as $1 \mu \mathrm{M}$ decreases human germ cell number by increasing apoptosis, but has no effect in mice (Fig. 7) (unpublished data).

We have shown that gonocytes were highly sensitive to irradiation even at doses as low as 0.1 and 0.2 Gy, and died by apoptosis. Sertoli cells were less affected, although their proliferation was modified. These effects involve the p53 pathway. Irradiation had no effect on testosterone secretion or on the expression of steroidogenic enzymes by Leydig cells [17] (Fig. 7). Lastly, we have demonstrated for the first time that phthalates, in particular MEHP (mono-2-ethylhexyl phthalate), an industrial chemical found in many products, alter the development of the germ cell lineage in human. However, in contrast to findings in rats, phthalates did not affect steroidogenesis [18]. These results 
highlight the specificity of the human model compared with rodent models. In the current environmental context, this highlights the need for such experiments on human fetal testis as a public health priority.

\section{Conclusion}

We have set up methods to study the development of the human fetal testis, which has particular characteristics compared with rodent testis. We have developed an organotypic culture system which appears to be a suitable model for studying the regulation or disruption of testicular development. Using this model, we have shown species-specific responses to different factors. Our findings provide important insight into the potential role of exposure to environmental pollutants (physical factors, in particular ionizing radiation, cadmium and endocrine disruptors such as phthalates) during fetal testicular development and their potential deleterious effects on male fertility in adulthood.

Acknowledgements: We thank the staff of the Department of Obstetrics and Gynecology of the Antoine Béclere Hospital (Clamart, France). We are grateful to N. Di Clemente (INSERM U782, Clamart, France) for donating the antibody anti-AMH. We thank Aurélie Gouret for her skillful secretarial assistance. This work was supported by Université Paris Diderot-Paris 7, CEA, INSERM, Agence Nationale pour la Recherche (ANR), Electricité De France, the Toxicologie Nucléaire Environnementale program and Agence Française de Sécurité Sanitaire de l'Environnement et du Travail (AFFSET), V.M. holds a fellowship from the Ministere de l'Education Nationale de la Recherche et de la Technologie. R.L. holds a fellowship from the Commissariat í l'Energie Atomique.

\section{References:}

[ 1] Wartenberg H. Differentiation and development of the testes Raven Press, 1989, pp. 67-118.

[ 2] Gondos B. Development and differentiation of the testis and male reproductive tract. In: Steinberger A, Steinberger E Testicular development, structure, and function. New York: Raven Press, 1980. pp. 3-20.

[ 3] Bendsen E, Byskov AG, Laursen SB, Larsen HP, Andersen CY, Westergaard LG. Number of germ cells and somatic cells in human fetal testes during the first weeks after sex differentiation. Hum Reprod. 2003;18:13-8.

[ 4] O'Shaughnessy PJ, Baker PJ, Monteiro A, Cassie S, Bhattacharya S, Fowler PA. Developmental changes in human fetal testicular cell numbers and messenger ribonucleic acid levels during the second trimester. J Clin Endocrinol Metab. 2007;92:4792-801.
[ 5] Olaso R, Habert R. Genetic and cellular analysis of male germ cell development. J Androl. 2000;21:497-511.

[ 6] Gaskell TL, Esnal A, Robinson LL, Anderson RA, Saunders PT. Immunohistochemical profiling of germ cells within the human fetal testis: identification of three subpopulations. Biol Reprod. 2004;71:2012-21.

[ 7] Hilscher B, Hilscher W, Bulthoff-Obnolz B, Krämer U, Birke A, Pelzer H, Grauss G. Kinetics of gametogenesis. I. Comparative histological and autoradiographic studies of oocytes and transitional prospermatogonia during oogenesis and prespermatogenesis. Cell Tissue Res. 1974;154:443-70.

[ 8] Pauls K, Schorle H, Jeske W, Brehm R, Steger K, Wernert N, Buttner R, Zhou H. Spatial expression of germ cell markers during maturation of human fetal male gonads: an immunohistochemical study. Hum Reprod. 2006;21:397-404.

[ 9] Rajpert-De Meyts E. Developmental model for the pathogenesis of testicular carcinoma in situ: genetic and environmental aspects. Hum Reprod Update. 2006;12:303-23.

[10] Huhtaniemi I, Pelliniemi L. Fetal Leydig cells: cellular origin, morphology, life span, and special functional features. Proc Soc Exp Biol Med. 1992;201:125-40.

[11] Rabinovici J, Jaffe R. Development and regulation of growth and differentiated function in human and subhuman primate fetal gonads. Endocr Rev. 1990;11:532-57.

[12] Reyes F, Winter J, Faiman C. Endocrinology of the fetal testis. In: Burger H, de Kretser D The testis. New York: Raven Press, 1989. p. 119-42.

[13] Livera G, Delbes G, Pairault C, Rouiller-Fabre V, Habert R. Organotypic culture, a powerful model for studying rat and mouse fetal testis development. Cell Tissue Res. 2006;324:507-21.

[14] Rouiller-Fabre V, Levacher C, Pairault C, Racine C, Moreau E, Olaso R, Livera G, Migrenne S, Delbes G, Habert R. Development of the foetal and neonatal testis. Andrologia. 2003;35:79-83.

[15] Livera G, Rouiller-Fabre V, Durand P, Habert R. Multiple effects of retinoids on the development of Sertoli, germ and Leydig cells of fetal and neonatal rat testis in culture. Biol Reprod. 2000;62:1303-14.

[16] Lambrot R, Coffigny H, Pairault C, Donnadieu AC, Frydman R, Habert R, Rouiller-Fabre V. Use of organ culture to study the human fetal testis development: effect of retinoic acid. J Clin Endocrinol Metab. 2006;91:2696-703.

[17] Lambrot R, Coffigny H, Pairault C, Lecureuil C, Frydman R, Habert R, Rouiller-Fabre V. High radiosensitivity of germ cells in human male fetus. J Clin Endocrinol Metab. 2007;92:2632-9.

[18] Lambrot* R, Muczynski* V, Lecureuil C, Angenard G, Coffigny $\mathrm{H}$, Pairault C, Moison D, Frydman R, Habert R, Rouiller-Fabre V. Phthalates impair germ cell development in the human fetal testis in vitro without change in testosterone production. Environ Health Perspect. 2009;117:32-7. 